\title{
Analisis Penggunaan Aplikasi SIMDA Dalam Implementasi Peraturan Pemerintah Nomor 71 Tahun 2010 Di Kabupaten Maluku Tenggara
}

\author{
ASTUTY VERONIKA LAURA HARBELUBUN ${ }^{1}$, LINTJE KALANGI ${ }^{2}$, LINDA LAMBEY ${ }^{3}$ \\ 1,2,3Program Magister Akutansi, Fakultas Ekonomi dan Bisnis Universitas Sam Ratulangi \\ email: astuty.v.l.harbelubun@gmail.com ${ }^{1}$, lintjekalangi@yahoo.com² ${ }^{2}$ lindalambey@yahoo.com ${ }^{3}$
}

\begin{abstract}
Implementing government regulation number 71 Year 2010 has brought a new challenge into local government accounting including Southeast Maluku District. This research aims to analyse SIMDA application based on Geverment Regulation number 71 Year 2010 in Southeast Maluku. The purposes of accrual basis accounting Entities/Reports are to measure the actual performances and the service efficiency provided by local government. This is a qualitative exploratory research. It is an inductive approach, in which actual evidences or findings shape the conclusion. Data were collected by observation, indepth interviews and documentation. Data were validated by triangulation of sources and methods. This study concludes: (1) SIMDA application is supported by roles of LKPD, Internal control system, Communication and Commitment (2) Human Resources are evidenced to createobstacles in its implementation of Government Regulation number 71 Year 2010
\end{abstract}

Keywords: SIMDA application, Government Accounting Standar Implementation, Accrual Basis.

\begin{abstract}
Abstrak. Implementasi Peraturan Pemerintah Nomor 71 Tahun 2010 membawa tantangan baru dalam dunia akuntansi pemerintah daerah termasuk di Kabupaten Maluku Tenggara menggunakan Aplikasi SIMDA. Penelitian ini bertujuan untuk menganalisis penggunaan Aplikasi SIMDA dalam Implementasi Peraturan Pemerintah Nomor 71 Tahun 2010 di Kabupaten Maluku Tenggara. Manfaat Akuntansi berbasis akrual mengukur kinerja sesungguhnya dari Entitas Akuntansi/Pelaporan dan Mengukur efisiensi pelayanan yang dilakukan oleh pemda. Dalam Penelitian ini, metode penelitian yang digunakan oleh peneliti adalah metode eksploratori (exploratory approach) dengan pendekatan induktif, yaitu suatu pendekatan dengan mengambil suatu kesimpulan secara umum dari fakta-fakta nyata dilapangan. Teknik pengumpulan data yang ditempuh dalam penelitian ini adalah melalui pengamatan/observasi (observation), wawancara mendalam (indepth interview), dan dokumentasi (documentation). Sedangkan validitas data yang digunakan adalah triangulasi sumber dan triangulasi metode. Hasil analisis dan pembahasan dapat disimpulkan bahwa: bahwa penunjang penggunaan Aplikasi SIMDA dalam Implementasi Peraturan Pemerintah Nomor 71 Tahun 2010 di Kabupaten Maluku Tenggara adalah Peranan LKPD, Sistim Pengendalian Internal, Komunikasi, Komitmen, sedangkan Sumber Daya Manusia menjadi faktor penghampat penggunaan Aplikasi SIMDA dalam Implementasi Peraturan Pemerintah Nomor 71 Tahun 2010
\end{abstract}

Kata Kunci: Aplikasi SIMDA, Implementasi Standar Akuntansi Pemerintahan, Akrual Basis

\section{Pendahuluan}

Sejarah akuntansi pemerintahan di Indonesia, dimulai dengan diwajibkannya pemerintah Indonesia agar memiliki Standar Akuntansi Pemerintahan dalam pasal 3 ayat (1) Undang-Undang No. 17 tahun 2003 tentang keuangan Negara, yang mengharuskan keuangan Negara dikelola secara tertib, taat pada peraturan perundang-undangan, efisien, efektif, ekonomis, transparan dan bertanggung jawab dengan memperhatikan rasa keadilan dan kepatutan, dapat semakin diwujudkan. Pertama kalinya pemerintah Indonesia memiliki Standar dengan ditetapkannya Peraturan Pemerintah Nomor 24 Tahun 2005, yang kemudian diubah dengan Peraturan Pemerintah Nomor 71 Tahun 2010, Kedua Peraturan Menteri Keuangan (PMK) Nomor 283/2011 tentang Pedoman umum Sistem Akuntansi Pemerintahan (PUSAP) dan Ketiga Peraturan Menteri Dalam Negeri Nomor 64 Tahun 2013 tentang Penerapan Standar Akuntansi Pemerintah Berbasis Akrual pada Pemerintah Daerah.

Kabupaten Maluku Tenggara merupakan salah satu kabupaten di Indonesia yang pada tahun 2015 telah menerapkan standar akuntansi pemerintahan berbasis akrual dan mendapat opini Wajar Tanpa Pengecualian (WTP) dari Badan Pemeriksa Keuangan (BPK) Perwakilan Propinsi Maluku. Penerapan sistem akuntansi berbasis akrual di pemerintahan merupakan tantangan baru, sehingga perlu didukung oleh sumber daya manusia yang meliputi pembuat dan pengguna informasi keuangan, sarana dan prasarana serta sistem informasi yang digunakan pada Pemerintah Kabupaten Maluku Tenggara adalah SIMDA yang merupakan sistem yang dikembangkan oleh BPKP, SIMDA telah digunakan Pemerintah Kabupaten Maluku Tenggara dari tahun 2008 sampai sekarang. Dalam rangka Implementasi Peraturan Pemerintah Nomor 71 Tahun 2010 
oleh BPKP telah mengembangkan SIMDA versi 27.2.7.07 sampai dengan sekarang telah dikembangkan dengan SIMDA versi 27.2.7.11. Di sisi lain tuntutan transparansi dalam sistem pemerintah semakin meningkat pada era reformasi saat ini, tidak terkecuali transparansi dalam pengelolaan keuangan.

Laporan Keuangan 2015 Pemerintah Kabupaten Maluku Tenggara telah melakukan Restatement dalam mengimplementasikan SAP basis Akrual adalah untuk neraca, karena neraca 2014 ketika disusun belum menerapkan seutuhnya standar kebijakan berbasis akuntansi akrual. Restatement dilakukan untuk akun-akun yang kebijakan akuntansinya berbeda/belum diterapkan saja misalnya penyisihan piutang, beban dibayar dimuka, penyusutan aset tetap dan pengakuan hutang atas kejadian yang telah terjadi tetapi kewajibannya belum dibayarkan. Tahapannya yaitu akun disesuaikan dengan perlakuan akuntansi sesuai Standar Kebijakan Akuntansi yang baru, dalam rangka memahami permasalahan terkait penggunaan Aplikasi SIMDA dalam implementasi Peraturan Pemerintah Nomor 71 Tahun 2010 dimana perlu dilakukan koreksi dan penyesuaianpenyesuaian yang mendasar atas akun-akun tertentu.

Aplikasi SIMDA Keuangan sebagai alat bantu (tools) dalam rangka pengelolaan keuangan daerah yang saat ini telah banyak diimplementasikan di pemerintah daerah. Kondisi tersebut memberikan berbagai masukan dan pengalaman dalam melakukan perbaikan sistem informasi secara terus menerus agar hambatan implementasi dapat tereliminasi. Kondisi yang menyebabkan terhambatnya implementasi utamanya disebabkan oleh perbedaan antara kebijakan pengelolaan keuangan yang diterapkan pada aplikasi (system requirement) dan kebijakan pengelolaan keuangan yang diterapkan oleh pemerintah daerah. Hal ini terjadi karena Aplikasi SIMDA Keuangan dikembangkan berdasarkan ketentuan yang belaku untuk dapat diimplementasikan di setiap pemerintah daerah. Oleh sebab itu dibutuhkan kebijakan sistem pengelolaan yang harus diterapkan di pemerintah daerah sesuai dengan Aplikasi SIMDA Keuangan.

Gambaran tentang Laporan Realisasi Anggaran Pendapatan dan Belanja Daerah menunjukkan adanya peningkatan realisaisi pendapatan dan belanja daerah dari tahun 2014 sampai dengan tahun 2016, pada tahun 2014 masih menggunakan Peraturan Pemerintah Nomor 24 Tahun 2005 jika dibandingkan pendapatan daerah di Pemerintah Kabupaten Maluku Tenggara dari tahun 2014 sampai dengan 2016 setelah diterapkannya Peraturan Pemerintah Nomor 71 Tahun 2010, mengalami peningkatan sebesar 72,24 persen dan 62,15 persen, yang dapat dilihat pada lampiran 7. Laporan Keuangan Pemerintah Daerah merupakan kompilasi dari laporan keuangan SKPD, dalam pengamatan penulis yang juga merupakan pembuat laporan keuangan pemerintah daerah peranan SKPD dalam menyusun laporan keuangan sampai sekarang belum mandiri hal ini disebabkan karena masih ada ketergantungan pada bidang akuntansi pada Badan Keuangan dan Aset Daerah selaku PPKAD hal ini dapat dilihat dalam Laporan Hasil Pemeriksaan BPK nomor: 04.B/HP/XIX.AMB/06/2016 ditemukan Pengendalian dalam Penyusunan Laporan Keuangan Kurang Memadai Hasil pemeriksaan atas proses penyusunan Laporan Keuangan Pemerintah Kabupaten Maluku Tenggara Tahun 2015.

Kerangka Pemikiran, Kerangka pemikiran pada penelitian ini tentang pengelolaan keuangan daerah, menentukan topik penelitian yaitu Analisis Penggunaan Aplikasi SIMDA dalam Implementasi Peraturan Pemerintah Nomor 71 Tahun 2010. Langkah berikutnya adalah fokus penelitian tentang Analisis Penggunaan Aplikasi SIMDA dalam Implementasi Peraturan Pemerintah Nomor 71 Tahun 2010 yang didukung dengan wawancara, observasi dan studi dokumentasi. Selanjutnya adalah tahapan pengumpulan data, pengolahan data, periksa keabsahan data dan penyusunan laporan penelitian.

\section{Gambar 1}


Kerangka Pemikiran

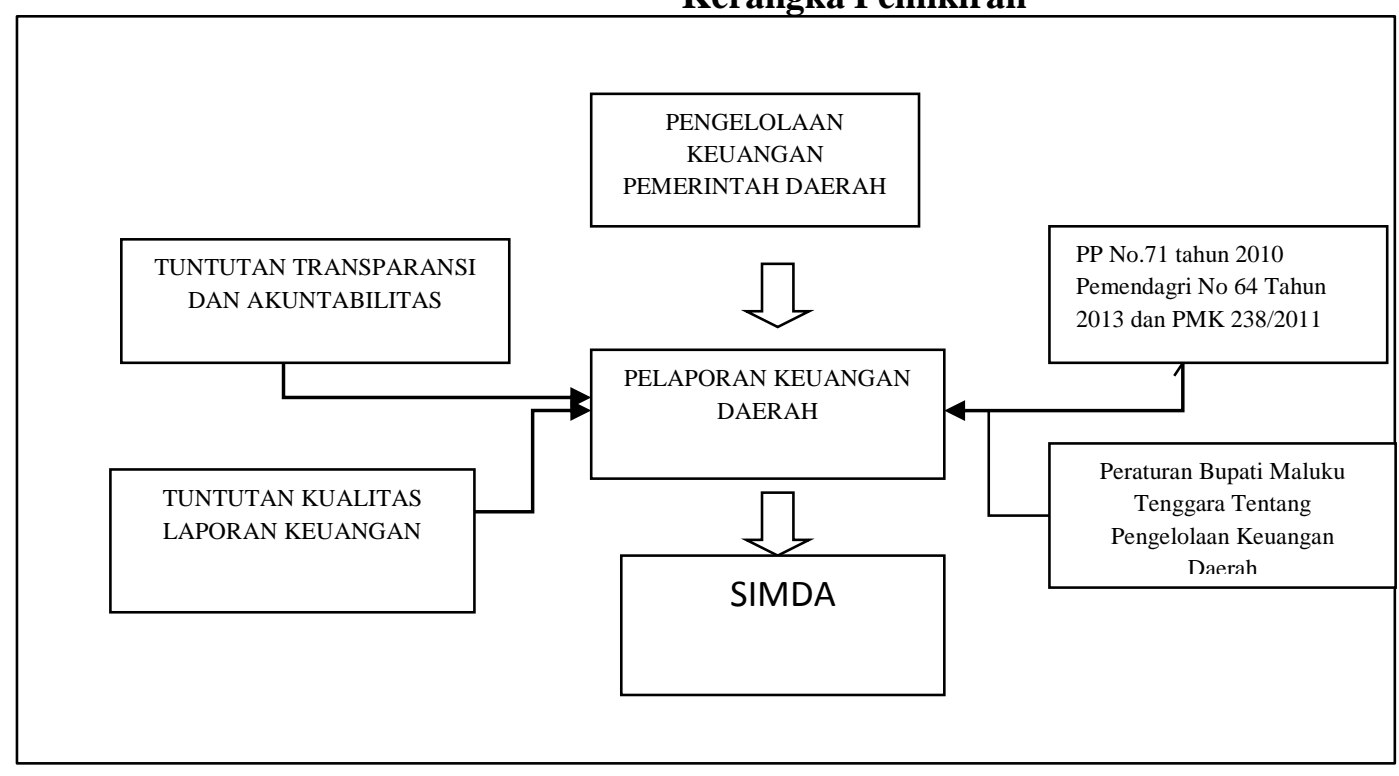

\section{Metode Penelitian}

Metode Penelitian adalah cara-cara berpikir, berbuat untuk dipersiapkan secara baik untuk mencapai tujuan penelitian. Dalam Penelitian ini, metode penelitian yang digunakan oleh peneliti adalah metode eksploratori (exploratory approach) dengan pendekatan induktif, yaitu suatu pendekatan dengan mengambil suatu kesimpulan secara umum dari fakta-fakta nyata dilapangan. Pendekatan kualitatif menurut Sugiyono (2008: 14) adalah merupakan metode análisis yang berlandaskan pada filsafat postpositivisme, digunakan untuk meneliti pada kondisi objek yang alamiah, dimana peneliti adalah sebagai instrumen kunci. Metode eksploratori menurut Arikunto (2010:32), adalah metode penelitian yang bertujuan untuk menggali suatu informasi. Amirin (2009) mendefinisikan Penelitian eksploratif merupakan salah satu pendekatan penelitian yang digunakan untuk meneliti sesuatu (yang menarik perhatian) yang belum diketahui, belum dipahami, belum dikenali, dengan baik. Menurut Ibrahim (2015:60) pengertian penelitian eksploratif adalah cara kerja penelitian yang dimaksud untuk menemukan lebih jauh dan mendalam terhadap kemungkinan-kemungkinan lain dari masalah yang diteliti.

Teknik pengumpulan data dalam penelitian kualitatif menurut Indrawan dan Yaniawati (2016:133) adalah wawancara, studi dokumentasi untuk menghimpun data (teks) atau gambar (foto), dan observasi atau pengamatan partisipatif. Menurut Sugiyono (2014:62), teknik pengumpulan data merupakan langkah yang paling strategis dalam penelitian, karena tujuan utama dalam penelitian adalah mendapatkan data. Tanpa mengetahui teknik pengumpulan data, maka tidak mungkin akan mendapatkan data yang memenuhi standar data yang ditetapkan.

Wawancara dilakukan kepada 2 orang BPK Perwakilan Propinsi Maluku, 2 orang BPKP, Bupati, Kepala BKAD, Sekretaris BKAD, Inspektur, Kepala bidang di BKAD dan Pemeriksa Inspektorat.

\section{Analisis dan Pembahasan}

Penelitian ini dilakukan selama 4 (Empat) bulan yakni antara bulan Mei 2017 hingga bulan Agustus 2017. Instrumen penelitian pendukung adalah pedoman wawancara, instru-men observasi lapangan, alat perekam berupa audio recorder untuk merekam pelaksanaan wawancara dengan informan yang hasilnya menjadi transkrip data Data hasil penelitian yang dihimpun baik melalui wawancara, dokumentasi dan observasi kemudian dilakukan organisasi data. Peneliti mengetik hasil interview menjadi interview transcription, kemudian melakukan content analysis untuk menganalisis interview transcription yang ditranscribe dari hasil wawancara atau dapat dijelaskan bahwa setelah melakukan wawancara, analisis data dimulai dengan membuat transkrip hasil wawancara, dengan cara memutar kembali rekaman hasil wawancara, mendengarkan dengan seksama, kemudian menuliskan kata-kata yang didengar sesuai dengan apa yang ada direkaman tersebut kemudian melakukan kategorisasi/coding atau penentuan tema berdasarkan rumusan masalah dan pertanyaan penelitian yang diajuhkan peneliti. 
Berdasarkan hasil penelitian yang diperoleh dari wawancara, observasi dan studi dokumentasi, selanjutnya dilakukan interpretasi atas temuan yang ada sesuai dengan dengan teori/konsep yang mendukung hasil penelitian. Peneliti menggunakan uji credibility (kredibilitas) pada penelitian dimana kepercayaan terhadap data hasil penelitian kualitatif antara lain dilakukan dengan perpanjangan pengamatan, peningkatan ketekunan dalam penelitian, triangulasi, dimana interview transkip ditanda tangani oleh responden dan coding dibaca/disahkan oleh dosen pembimbing 2 (dua), kemudian dilakukan member check. Ditemukan 6 (enam) faktor dalam analisis penggunaan aplikasi SIMDA dalam Implementasi PP 71 Tahun 2010 di Kabupaten Maluku Tenggara, yaitu Aplikasi SIMDA, dasar hukum, komunikasi, komitmen, Sistem pengendalian internal, sumber daya manusia dan peran LKPD.

Adapun analisis terhadap hasil penelitian dan pembahasan dapat diuraikan sebagai berikut:

\section{Penggunaan Aplikasi SIMDA pada Laporan Keuangan Pemerintah Daerah di Kabupaten Maluku Tenggara}

Guna meningkatkan tuntutan transparansi dan akuntabilitas atas Pengelolaan Keuangan Daerah secara ekonomis, efisien, dan efektif (value for money), maka salah satu cara yang dilakukan oleh Pemerintah Daerah adalah dengan menggunakan Aplikasi SIMDA yang diatur dalam peraturan Bupati Maluku Tenggara tentang Kebijakan Akuntansi. Aplikasi SIMDA digunakan dalam proses perencanaan, penganggaran, penatausahaan sampai dengan pelaporan keuangan.

Informasi yang telah diuraikan memperjelas bahwa penggunaan Aplikasi SIMDA dalam proses perencanaan, penganggaran, penatausahaan dan pelaporan sangat membantu. Pengelolaan keuangan darah adalah keseluruhan kegiatan yang meliputi perencanaan, pelaksanaan, penatausaaan, pelaporan, pertanggungjawaban, dan pengawasan daerah dalam Rosmery Elsye et al., (2016; 2). Menurut Peraturan Menteri Dalam Negeri No. 13 Tahun 2006 tentang Pedoman Pengelolaan Keuangan Daerah Bab I, bagian pertama tentang ketentuan umumnya menyebutkan bahwa yang dimaksud dengan keuangan daerah dalam rangka penyelenggaraan pemerintah daerah yang dapat dinilai dengan uang termasuk didalamnya segala bentuk kekayaan yang berhubungan dengan hak dan kewajiban daerah tersebut. Dalam bagian ketiga pasal 4 menyebutkan bahwa pengelolaan keuangan daerah dilakukan dengan tertib, taat pada peraturan perundangundangan, efektif, efisien, ekonomis, transparan dan bertanggungjawab dengan memperhatikan asas keadilan, kepatutan dan manfaat untuk masyarakat. Selanjutnya pada bagian sepuluh pasal 232 ayat 2 dan Peraturan Pemerintah Nomor 8 tentang Laporan Keuangan dan kinerja Instansi Pemerintah. Laporan Keuangan adalah bentuk pertanggungjawaban pengelolaan keuangan negara/daerah selama suatu periode, Kinerja adalah keluaran/hasil dari kegiatan/program yang hendak atau telah dicapai sehubungan dengan penggunaan anggaran dengan kuantitas dan kualitas terukur dan Laporan Kinerja adalah ikhtisar yang menjelaskan secara ringkas dan lengkap tentang capaian Kinerja yang disusun berdasarkan rencana kerja yang ditetapkan dalam rangka pelaksanaan APBN/APBD.

Dalam pengelolaan keuangan dengan menggunakan Aplikasi SIMDA mulai dari perencanaan, penganggaran, penatausahaan mulai penginputan RKA pembuatan DPA penginputan Surat Ketetapan Pajak Daerah (SKPD) dan Surat Ketetapan Retribusi Daerah (SKRD) sampai dengan bukti penerimaan dan penyetoran ke Bank demikaian juga untuk belanja mulai dari penginputan bukti belanja penginputan penerimaan pajak penyetoran pajak, pembuatan SPP, SPM sampai dengan SP2D baik itu untuk belanja dengan GU/ UP/ TU kemudian dilakukan posting. Rosmery Elsye (2011: 116) posting merupakan proses pemindahan informasi, minimal berupa tanggal transaksi dan jumlah rupiah dalam buku jurnal ke buku besar yang berhubungan dengan masing-masing ayat jurnal.

Menurut Rosmery Elsye et al $(2016 ; 112)$ siklus akuntansi adalah serangkaian tahapan yang harus dilalui untuk mengubah input dalam bentuk dokumen transaksi keuangan sehinggah menghasilkan output berupa laporan keuangan. Setelah semua proses perencanaan, pelaksanaan, penatausahaan dilakukan secara benar, berikut adalah langkah-langkah yang harus dilakukan dalam Penyusunan LKPD dengan menggunakan SIMDA Keuangan:

\section{Bagaimana laporan keuangan sebelum dan setelah ditetapkan Peraturan Pemerintah Nomor 71 Tahun 2010 tentang Standar Akuntansi Pemerintahan (SAP) di Pemerintah Kabupaten Maluku Tenggara}

Pada bagian ini peneliti akan membahas tema yang ke dua yaitu dasar hukum/akrual basis yang merupakan landasan bagi penyusunan laporan keuangan dan bagaimana laporan keuangan disusun sesuai dengan peraturan perundang-undangan yang berlaku. 
Laporan keuangan sebelum dan sesudah Peraturan Pemerintah Nomor 71 Tahun 2010 di Pemerintah Kabupaten Maluku Tenggara dalam proses perencanaan, pengganggaran, penatausaahaan sampai dengan pelaporan sebagaimana diamanatkan oleh peraturan perundang-undangan. Rangkuman hasil analisis dan pembahasan tentang Laporan keuangan sebelum dan sesudah penerapan Peraturan Pemerintah Nomor 71 Tahun 2010 di Kabupaten Maluku Tenggara dapat dilihat pada tabel

Peraturan Pemerintah Nomor 24 Tahun 2005 tentang Standar Akuntansi Pemerintahan yang bisa sebut sebagai (SAP). Standar Akuntansi Pemerintah tersebut menganut basis kas menuju akrual (cash toward accrual), yaitu menggunakan basis kas untuk pengakuan transaksi pendapatan, belanja dan pembiayaan, dan basis akrual untuk pengakuan aset, kewajiban, dan ekuitas dana. Namun, penerapan Peraturan Pemerintah Nomor 24 Tahun 2005 masih bersifat sementara sebagaimana diamanatkan dalam Pasal 36 ayat (1) Undang Undang Nomor 17 Tahun 2003 tentang Keuangan Negara yang menyatakan bahwa selama pengakuan dan pengukuran pendapatan dan belanja berbasis akrual belum dilaksanakan, digunakan pengakuan dan pengukuran berbasis kas.

Dengan ditetapkannya Peraturan Pemerintah Nomor 71 Tahun 2010, maka penerapan sistem akuntansi pemerintahan berbasis akrual telah mempunyai landasan hukum. Dan hal ini berarti juga bahwa Pemerintah mempunyai kewajiban untuk menerapkan SAP yang baru yaitu SAP berbasis akrual tersebut. Hal ini sesuai juga dengan pasal 32 UU No. 17 tahun 2003 yang mengamanatkaan bahwa bentuk dan isi laporan pertanggungjawaban pelaksanaan APBN/APBD disusun dan disajikan sesuai dengan SAP. Dan hal ini ditegaskan dalam pasal 4 ayat (1) PP No. 71 Tahun 2010 menyebutkan bahwa Pemerintah menerapkan SAP Berbasis Akrual. SAP tersebut disusun oleh Komite Standar Akuntansi Pemerintahan (KSAP) yang independen dan ditetapkan dengan Peraturan Pemerintah setelah terlebih dahulu mendapat pertimbangan dari Badan Pemeriksa Keuangan (BPK).

Faktor-faktor pendukung dan penghambat penggunaan Aplikasi SIMDA dalam implementasi Peraturan Pemerintah Nomor 71 Tahun 2010, tentang Standar Akuntansi Pemerintah (SAP) di Pemerintah Kabupaten Maluku Tenggara

Pada bagian ini kita akan membahas tema yang 3, 4, 5, 6, dan 7 yang merupakan faktor pendukung dan penghambat penggunaan Aplikasi SIMDA dengan Peraturan Pemerintah Nomor 71 Tahun 2010 di Kabupaten Maluku Tenggara. Pemerintah Kabupaten Maluku Tenggara dalam proses perencanaan, pengganggaran, penatausaahaan sampai dengan pelaporan sebagaimana diamanatkan oleh peraturan perundang-undangan, semuanya tidak lepas dari berbagai faktor faktor pendukung dan penghambat penggunaan Aplikasi SIMDA dalam implementasi Peraturan Pemerintah Nomor 71 Tahun 2010, tentang Standar Akuntansi Pemerintah (SAP). Dari hasil penelitian yang peneliti lakukan, didapati 4 (lima) faktor pendukung penggunaan Aplikasi SIMDA dalam implementasi Peraturan Pemerintah Nomor 71 Tahun 2010 di Pemerintah Kabupaten Maluku Tenggara yaitu: peran LKPD, SPI, komunikasi dan komitmen, sedangkan faktor penghambat yaitu Sumber Daya Manusia.

Peranan LKPD, khususnya dalam penyusunan laporan keuangan pemerintah daerah melakukan penyusunan LKPD berdasarkan ketentuan perundang-undangan. Perencanaan dan penganggaran merupakan proses yang terintegrasi, oleh karenanya output dari perencanaan adalah penganggaran (Bastian 2009:10), dan output penatausahaan, sampai dengan pelaporan adalah LKPD. Pada Pemerintah Kabupaten Maluku Tenggara Peranan Penyusunan LKPD berada di Badan Keuangan dan Aset Daerah pada bidang Akuntansi. Dari beberapa pernyataan informan pada pembahasan sebelumnya diungkapkan LKPD Pemerintah Kabupaten Maluku Tenggara telah dilaksanakan sesuai peraturan perundang-undangan yang berlaku. Setiap entitas pelaporan mempunyai kewajiban untuk melaporkan upaya-upaya yang telah dilakukan serta hasil yang dicapai dalam pelaksanaan kegiatan secara sistematis dan terstruktur pada suatu periode pelaporan untuk berbagai kepentingan seperti: (a) Akuntabilitas (b) Manajemen (c) Transparansi dan (d) Keseimbangan Antar generasi (Intergenerational Equity).

Sistem Pengendalian Internal, Dalam rangka pengelolaan keuangan yang baik tranparansi dan akuntabel pemerintah harus mengembangkan suatu sistem pengendalian internal sehingga tidak terjadi tumpang tindih (overlapping) atau kesalahan penggunaan otoritas maka didalam Aplikasi SIMDA sudah dirancang ada pemisahan fungsi-fungsi dalam pelaksanaan tugas pengelolaan keuangan.

Menurut Peraturan Pemerintah Nomor 60 Tahun 2008 tentang Sistem Pengendalian Intern Pemerintah adalah "Proses yang integral pada tindakan dan kegiatan yang dilakukan secara terus menerus oleh pimpinan dan seluruh pegawai untuk memberikan keyakinan memadai atas tercapainya tujuan organisasi melalui kegiatan yang efektif dan efisien, keandalan pelaporan keuangan, pengamanan aset 
negara, dan ketaatan terhadap peraturan perundang-undangan. 'Dengan adanya SPIP tersebut diharapkan dapat menciptakan kondisi dimana terdapat budaya pengawasan terhadap seluruh organisasi dan kegiatan sehingga dapat mendeteksi terjadinya sejak dini kemungkinan penyimpangan serta meminimalisir terjadinya tindakan yang dapat merugikan negara.

Pentingnya peran SPIP dalam rangka mencapai tujuan dan sasaran organisasi serta untuk mewujudkan tata kelola pemerintahan yang baik maka pimpinan instansi/organisasi harus dapat menjadikan penerapan Sistem Pengendalian Intern Pemerintah menjadi tanggung jawab bersama tidak hanya pada unit kerja terkecil tapi hingga kepada masing-masing individu. Selain itu perlu diingat bahwa SPIP bukan hanya upaya membentuk mekanisme administratif saja tetapi juga upaya melakukan perubahan sikap dan perilaku (soft factor). Peraturan yang ada bukan merupakan akhir namun merupakan awal dari langkah perbaikan. Oleh Karena itu, implementasi SPIP sangat bergantung kepada komitmen, teladan pimpinan dan niat baik dari seluruh elemen dan pejabat dan pegawai instansi pemerintah.

Sistem pengendalian internal terdiri atas kebijakan dan prosedur yang dirancang untuk memberikan kepastian yang layak bagi manajemen bahwa perusahaan telah mencapai tujuan dan sadarannya. Manajemen memiliki tiga tujuan umum dalam merancang system pengendalian internal yang efektif yaitu keandalan pelaporan keuangan, efisiensi dan efektifitas operasi, serta ketaatan pada hukum dan peraturan. Manajemen bertanggungjawab untuk menyiapkan laporan bagi para investor, kreditur dan pengguna lainnya. Tanggungjawab untuk memilih dan mengadopsi kebijakan akuntansi yang tepat, menyelenggarakan pengendalian internal yang memadai, serta menyajikan laporan keuangan yang wajar berada dipihak manajemen bukan auditor.

Dalam Aplikasi SIMDA telah disediakan otorisasi dalam pengopersian SIMDA sesuai dengan tugas dan tanggungjawab. Pengendalian Intern Akuntansi (Preventive Controls) Pengendalian Intern Akuntansi dibuat untuk mencegah terjadinya inefisiensi yang tujuannya adalah menjaga kekayaan perusahaan/pemerintah dan memeriksa keakuratan data akuntansi. Contoh: adanya pemisahan fungsi dan tanggung jawab antar unit organisasi, hal ini dimaksudkan demi terlaksananya pengelolaan keuangan yang baik, transparansi dan akuntabel.

Komitmen adalah masalah emosi/hati, bukan perkataan ataupun sekedar pikiran. Menurut Kaswan (2014; 117) Jika ingin menjadi pemimpin yang efektif, orang harus memiliki komitmen. Jika dikaji dari segi terminologis, istilah komitmen pada dasarnya berasal dari bahasa Latin yaitu dari kata "commiter" yang artinya adalah menyatukan, menggabungkan, mengerjakan, dan mempercayai. Jika diartikan dari asal katanya, maka komitmen merupakan sikap setia dan tanggung jawab yang ditunjukkan oleh seseorang yang telah memutuskan untuk bergabung ke dalam aktivitas keanggotaan lembaga tertentu. Menurut para ahli sendiri, pengertian komitmen adalah suatu janji yang diucapkan seseorang kepada dirinya sendiri dan orang lain, yang dicerminkan dari setiap tindakan atau pun perilaku yang dijalankannya dan komitmen sangat berkaitan erat dengan watak, sifat, dan karakter yang ada dalam diri seseorang.

Komtimen organisasional menurut Ivancevich (2007:234) adalah perasaan idenifikasi, keterlibatan, dan kesetiaan yang diekspresikan oleh pegawai terhadap organisasi. Berdasarkan pengertian tersebut dapat diidentifikasi bahwa komitmen terhadap organisasi melibatkan tiga sikap yaitu, rasa identifikasi dengan tujuan organisasi, perasaan terlibat dalam tugas-tugas organisasi, dan perasaan setia terhadap organisasi. Bukti penelitian menunjukkan bahwa tidak adanya komitme organisasional dapat mengurangi efektivitas organisasi.

Pada Pemerintah Kabupaten Maluku Tenggara staf pelaksana memiliki sikap atau perspektif yang berbeda dengan pembuat kebijakan, maka proses implementasi kebijakan juga menjadi tidak efektif yang dipengaruhi oleh situasi dan motivasi. Selain itu komitmen organisasi yang dirasakan para pegawai di Kabupaten Maluku Tenggara saat ini terlihat kurang kuatnya keterikatan pegawai secara emosional serta keterlibatan pegawai pada tempat kerja, kurang perhatian terhadap rekan kerja dan kondisi tempat kerja menjadi salah satu indikasi lemahnya komitmen organisasi para pegawai. Sehingga timbul sikap keengganan untuk melakukan perubahan, Padahal jika komitmen organisasi ini tertanam kuat (baik) pada diri para pegawai akan berdampak pada kinerja mereka seperti yang dikemukkan oleh manajemen puncak yang telah berkomitmen dan keinginan untuk lebih maju dalam pengelolaan keuangan.

Komunikasi, Untuk mendukung terlaksananya Analisis Penggunaan Aplikasi SIMDA dalam Peraturan Pemerintah Nomor 71 Tahun 2010, perlu dilihat penerapan Peraturan Pemerintah dengan penggunaan aplikasi SIMDA, dengan demikian perlu dikomunikasikan secara tepat dengan para pelaksana. Penerapan akan berjalan efektif apabila ukuran-ukuran dan tujuan-tujuan penerapan dipahami oleh individu yang bertanggung jawab dalam pencapaian tujuan kebijakan, dalam hal ini kebijakan penerapan Peraturan 
Pemerintah Nomor 71 Tahun 2010. Untuk itu dibutuhkan komunikasi yang tepat sehingga kebijakan dapat dilaksanakan dengan tepat pula.

Pemerintah Kabupaten Maluku Tenggara selalu mengatasi permasalahan dengan komunikasi. Komunikasi menjadi salah satu faktor penunjang dalam penggunaan Aplikasi SIMDA, Aplikasi SIMDA merupakan Aplikasi yang dikeluarkan oleh BPKP oleh sebab itu untuk dapat menghasilkan pengelolaan keuangan yang baik perlu melakukan komunikasi yang baik antara pemerintah daerah dengan BPKP tetapi bukan dalam rangka ketergantungan tetapi dalam rangka penambah pemahaman tentang Aplikasi SIMDA itu sendiri.

Dari berbagai pernyataan informan dan pendapat yang telah diuraikan di atas menunjukkan bahwa penerapan/implementasi kebijakan dipengaruhi oleh komunikasi yang baik kepada para implementor. Berdasarkan analisis tersebut tersebut, ditemukan bahwa Pemerintah Kabupaten Maluku Tenggara sampai saat ini untuk penggunaan aplikasi SIMDA dalam implementasi Peraturan Pemerintah Nomor 71 tahun 2010 telah didukung oleh adanya proses komunikasi yang efektif dan efisien dari semua pihak yang terkait sehingga informasi yang jelas tentang Aplikasi SIMDA dalam implementasi Peraturan Pemerintah Nomor 71 tahun 2010 sampai saat ini di Kabupaten Maluku Tenggara telah terwujud.

Sumber daya manusia, Faktor penghambat dalam Analisis Penggunaan Aplikasi SIMDA dalam Peraturan Pemerintah Nomor 71 Tahun 2010 selanjutnya adalah sumber daya manusia (SDM). Sumber Daya adalah faktor penting untuk implementasi kebijakan agar efektif. Komponen sumber daya meliputi jumlah staf, keahlian dari para pelaksana, informasi yang relevan, serta cukup untuk menerapkan kebijakan dan pemenuhan sumber-sumber terkait dalam pelaksanaan kebijakan. Dari hasil penelitian dilapangan yang dilakukan oleh peneliti terdapat sedikitnya 3 (tiga) aspek yang sangat berperan sehingga SDM menjadi salah satu penghambat Analisis Penggunaan Aplikasi SIMDA dalam Peraturan Pemerintah Nomor 71 Tahun 2010 di Kabupaten Maluku Tenggara.

Kenyataan yang ditemui dilapangan hanya saja ASN yang pernah mengikuti pengembangan kapasitas berupa bimtek/kursus/diklat tetapi tidak bisa merupakan factor untuk meningkatkan kapasitas SDM tetapi tingkat pendidikan yang berperan dalam pelaksanaan tugas seorang pengelolaan keuangan dalam membuat laporan keuangan dari pengalaman peneliti yang juga sebagai ASN diKabupaten Maluku Tenggara, saya merasa bimtek/kursus/diklat yang diikuti oleh ASN apalagi tempat pelatihannya jauh hanya untuk jalanjalan jadi tidak menghasilkan dalam rangka peningkatan ASN itu sendiri, sebagai contoh Badan Keuangan dan Aset Daerah telah melaksanakan bintek penguatan penyusunan laporan keuangan berbasis akrual di tahun 2015, yang melibatkan semua SKPD sekabupaten Maluku Tenggara yang dilaksanakan dijakarta, tetapi pada saat penyusunan laporan keuangan tahun 2016 SKPD belum dapat melaksanakan fungsinya sebagai entitas akuntansi ataupun sebagai entitas pelaporan.

SDM menjadi penghambat analisis penggunaan aplikasi SIMDA dalam implementasi Peraturan Pemerintah Nomor 71 tahun 2010 di Kabupaten Maluku Tenggara telah diuraikan diatas dengan sangat jelas dan didukung oleh pernyataan para informan, pertama, kualitas SDM yang ada di Kabupaten Maluku Tenggara masih ditempatkan tidak sesuai dengan keahlian atau latar belakang pendidikan sehingga mengakibatkan ASN kurang paham akan tugasnya. Kedua, PNS/ASN belum siap menghadapi perkembangan teknologi dan informasi, kurangnya kemauan untuk belajar dan mengadalkan pengalaman saja, Ketiga sudah ada kemampuan yang memadai dan sangat baik bila dibandingkan dengan kabupaten lain dipropinsi Maluku tetapi hanya ada level SKPKD dan Inspektorat, tapi level SKPD masih lemah dan keempat, belum maksimal pelaksanaan bimtek/kursus/diklat untuk pengembangan kapasitas ASN. Permasalahan tersebut berdampak pada ukuran kinerja ASN yang ditampilkan menjadi hasil kerja dalam bentuk kualitas maupun kuantitas pada organisasi yang mereka tempati, sehingga dibutuhkan manajemen sumber daya manusia yang baik demi tercapainya tujuan organisasi. Penilaian kinerja yang bertujuan pengembangan juga mencakup pemberian pedoman kinerja pegawai di kemudian hari. Umpan balik akan menyadarkan pegawai tentang kelemahan dan kekuatan kinerja massa lalu dan menentukan arah yang harus dipilih pegawai untuk memperbaikinya serta bagaimana mereka dapat meningkatkan keterampilan mereka di masa mendatang.

Dari teori yang diuraikan mengkonfirmasi bahwa SDM adalah faktor penting untuk implementasi kebijakan agar efektif. SDM yang tidak memadai (jumlah dan kemampuan) berakibat tidak dapat dilaksanakannya kebijakan secara sempurna serta tidak mampu melakukan pengawasan dengan baik. Jika jumlah staf pelaksana kebijakan terbatas, maka hal yang harus dilakukan adalah meningkatkan kemampuan/keterampilan para pelaksana untuk melakukan penerapan kebijakan. Untuk itu, SDM pada Pemerintah Kabupaten Maluku Tenggara khususnya ASN perlu ada manajemen SDM yang baik agar dapat 
meningkatkan kinerjanya. Komitmen sumber daya manusia ditentukan oleh manajemen sumber daya manusia yang memiliki pengembangan karier kerja sesuai dengan sikap, pengetahuan, keterampilan dan keahlian dalam menghadapi dinamika kerja yang terus maju dan kompetitif menghadapi berbagai kesenjangan dan permasalahan suatu organisasi kerja.

Penggunaan Aplikasi SIMDA dalam implementasi Peraturan Pemerintah Nomor 71 Tahun 2010 akan berjalan dengan baik apabila peningkatan Sumber Daya Manusia bukan saja dengan bintek/kursus/diklat tetapi dengan ASN/PNS mengfasilitasi PNS untuk menambah pengetahuan di bidang akuntansi kejejang yang lebih tinggi atau penerimaan PNS diprioritas yang berpendidikan S1 Akuntansi.

\section{Penutup}

Kesimpulan berdasarkan analisis terhadap hasil interview, observasi dan studi dokumen yang telah dilakukan oleh peneliti bahwa penggunaan aplikasi SIMDA memiliki peranan penting dalam Pelaporan Keuangan dalam Implementasi Peraturan Pemerintah Nomor 71 Tahun 2010 dan terdapat setidaknya 5 (lima) faktor yang pendukung dan 1 (satu) faktor penghambat penerapan PP 71 Tahun 2010 dengan menggunakan Aplikasi SIMDA di Pemerintah Kabupaten Maluku Tenggara. Berikut adalah kesimpulan yang didapat dari penelitian: Pemerintah Kabupaten Maluku Tenggara telah menggunakan Aplikasi SIMDA dalam pengelolaan keuangan Aplikasi SIMDA lebih efektif dan efisien. Aplikasi SIMDA dalam penerapannya masih memiliki kelemahan yang berasal dari aplikasi dan Sumber Daya Manusia, Peraturan Pemerintah Nomor 71 Tahun 2010 memiliki keunggulan tersendiri jika dibandingkan dengan Peraturan Pemerintah Nomor 24 Tahun 2005, Faktor penunjang Penggunaan Aplikasi SIMDA adalah peranan LKPD, sistem pengendalian internal, komitmen dan komunikasi, dan Faktor penghambat penggunaan Aplikasi SIMDA dalam Implementasi Peraturan Pemerintah Nomor 71 Tahun 2010 adalah Sumber Daya Manusia. Ada dua aspek yang terkait dengan faktor sumber daya manusia menjadi penghambat dalam penggunaan Aplikasi SIMDA, adalah sebagai berikut: Kualitas SDM, dimana masih banyak ASN ditempatkan tidak sesuai dengan keahlian atau latar belakang pendidikan sehingga mengakibatkan ASN kurang paham akan tugasnya dan PNS/ASN belum siap menghadapi perkembangan teknologi dan informasi, kurangnya kemauan untuk belajar dan mengandalkan pengalaman saja.

Saran Dalam hal peningkatan SDM ada beberapa hal yang dapat disarankan dan menjadi perhatian

bagi Pemerintah Kabupaten Maluku Tenggara dalam peningkatan penggunaan Aplikasi SIMDA dalam Implementasi Peraturan Pemerintah Nomor 71 Tahun 2010, kedepan antara lain: Pemerintah Kabupaten Maluku Tenggara perlunya melakukan metode peningkatan kapasitas SDM kepada ASN dalam penggunaan aplikasi SIMDA dalam implementasi Peraturan Pemerintah Nomor 71 tahun 2010 serta harus didukung manajemen ASN yang baik dalam menempatkan seseorang sesuai dengan latar belakang pendidikan dan keahliannya dalam rangka continuous improvement, Memberikan insentif atau penghargaan bagi staf pengelolaan keuangan yang baik, dan Penerimaan Pegawai Negeri Sipil yang berlatar pendidikan S1 Akuntansi

\section{DAFTAR PUSTAKA}

Abdul Hafiz Tanjung.2012. Akuntansi Pemerintahan Daerah. Bandung:

Abdul Abdul (2004) Manajemen Keuangan Daerah Yogyakarta

Abdulah Syukriy (2008) Akuntansi Pemerintah

Ahmadi dan Supriyono. 2006. Psikologi Belajar. Jakarta

Amirin. 2009. Objek, subjek, dan populasi penelitian. (online)

Arikunto. 2010. Prosedur Penelitian: Suatu pendekatan Pratik (Edisi Revisi). Jakarta: Rineka Cipta

Bastian. 2006. Akuntansi Sektor Publik: Suatu Pengantar. Jakarta: Erlangga.

Bohlander, George. and Scott Snell. 2010. Principles of Human Resource. Management, $15^{\text {th }}$ ed. Mason, $\mathrm{OH}$ : South Western - Cengage Learning

Bugin. 2015. Metodologi penelitian kualitatif. Jakarta: Rajawali Pers.

Creswell. 2012. Metodologi penelitian dan desain riset. Cileban Timur. Pustaka Belajar

Cristy Soputan, Julie J Sondakh, Steven Tangkuman (2015) dengan judul "Penyajian Laporan Keuangan

Pemerintah Berdasarkan PP Nomor 71 Tahun 2010 Tentang Standar Akuntansi Pemerintahan di

Provinsi Sulawesi Utara. Vol 3. No.1 Hal 98 -110

Dedi Noerdiawan (2006) Akuntalsi Sektor Publik. 
Agustinusn Johanes Djohan. 2016. 5 Pilar Kepemimpinan di Abad 21. Media Nusa Kreaktif. Malang.

Muslichah Erma Widiana. 2016. Referensi Variabel dan Indikator yang mempengaruhi Komitmen dan Kinerja Organisasi Pemerintah.

Rosmery Elsye, Dandang Suwanda, dan Umuh Muchidin. 2016. Dasar-dasar Akuntansi Akrual Pemerintah Daerah. Ghalia Indonesia. Bogor.

Sopiah. 2008. Perilaku Organisasional. Andi Yogyakarta.

Edwards, George C. III. 1980. Implementing Public Policy. Washington DC: Congresional, Quartely Press.

Effendy, Onong Uchjana. 2007. Ilmu Komunikasi (Teori dan Praktek). Bandung: PT. Remaja Rosdakarya.

Erikhenko. Peper akuntansi Pemerintahan.

Geoffrey Tickell (2010). Penerapan Standar Akuntansi Pemerintah berbasis Akrual di Fuji.

Hanifah Harsono. (2002). Implementasi Kebijakan dan Politik

Halens Ryanlie Ole (2014) dengan judul "Analisis Implementasi Sistem Informasi Manajemen Daerah (SIMDA) Terhadap Kualitas Laporan Keuangan SKPD (Studi Kasus Pada Dinas PPKAD Kabupatten Minahasa Tenggara). Vol 3. No.2 Hal 96-100

Wansyah, Hendra, Darwanis dan Usman Bakar. 2012. Pengaruh Kapasitas Sumber Daya Manusia, Pemanfaatan Teknologi Informasi dan Kegiatan Pengendalian Terhadap Nilai Informasi Pelaporan Keuangan SKPD pada Propinsi Aceh. Jurnal Akuntansi Pasca Sarjana Universitas Syiah Kuala 1 (1): 43-48, ISSN 2302-0164.

Ibrahim. 2015. Metodologi Penelitian kualitatif. Bandung: Alfabeta

Bastian Indra. 2006. Akuntansi Sektor Publik: Suatu Pengantar, Penerbit Erlangga - Jakarta

Kieso Donald E, Weygandt Jerry J dan Warfield Terry D. 2008. Akuntansi Intermediate Edisi ke Dua Belas Jilid 1. Jakarta: Erlangga

Lambey, Linda. Jennifer Waterhouse dan Brendan Boyle. 2013. Understanding Relationships in the Psychological Contracts of Indonesian Academics; 10\&Organisational Behaviour (Interpersonal behaviour, managerial thinking \& recognition, perception, values) Competitive Session. ANZAM.

Mahmudi. 2010. Analisis Laporan Keuangan Pemerintah Daerah. Edisi ke - 2. UPP STIM YKPN. Yogyakarta.

Mardiasmo. 2009. Akuntansi Sektor Publik. Yogyakarta

Modul BPKP. 2016. System Requirement simda 2.7 Revisi 2.7.11b

Moh.Mashudi Arif (2014) dengan judul "Analisis Kesiapan Pemerintah Daerah Dalam Penerapan Standar Akuntansi Pemerintahan Berbasis Akrual (Studi pada Pemerintah Daerah Kabupaten Bondowoso). Vol 3. No.2 Hal 96-104

Mohamad Alfian (2014) dengan judul "Analisis Faktor Pendukung Implementasi SIMDA dan Pengaruhnya Terhadap Kualitas Laporan Keuangan pada SKPD di Lingkungan Pemerintah Daerah Kabupaten Kulon Progo. Jurnal 3rd Economics \& Business Research Festival. Hal 143-260

Musfiqon. 2012. Panduan Lengkap Metodologi Penelitian Pendidikan. PT. Prestasi Pustakaraya. Jakarta.

Nawawi, Hadari. 2000. Administrasi Personel Untuk Peningkatan Produktivitas Kerja. Jakarta. Haji Intermedia.

Nugroho, Riant. 2014. Public Policy. Teori, Manajemen, Dinamika, Analisis, Konvergensi, dan Kimia Kebijakan. PT. Elex Media Komputindo. Kelompok Gramedia. Jakarta.

Nur Alfiani (2017) dengan judul "Pengaruh Implementasi Sistem Informasi Manajemen Keuangan Daerah (SIMDA), Kualitas Sumber Daya Manusia, Dan Dukungan Manajemen Puncak Terhadap Kualitas Laporan Keuangan Daerah pada Pemerintah Kabupaten Tegal. Vol 3. No.1 Hal 100-110

Nurdin dan Usman. 2002. Konteks implementasi

Nurul Hidayah, SE. AK. MSI. (2012). Modul Akuntansi Sektor Publik.

Partoni. 2001. Sistem/Basis pencatatan.

Peraturan Bupati No.50.a tahun 2016 Sistem Akuntansi Pemerintah Daerah Kabupaten Maluku Tenggara

Peraturan Bupati No.50.b tahun 2016 Kebijakan Akuntansi Pemerintah Daerah Kabupaten Maluku Tenggara

Peraturan Pemerintah Nomor 58 Tahun 2005 tentang Pengelolaan Keuangan Daerah.

Peraturan Menteri Keuangan No.283 tahun 2011Pedoman Umum Sistem Akuntansi Pemerintahan (PUSAP)

Peraturan Menteri Keuangan No.64 tahun 2013 tentang Penerapan Standar Akuntansi Pemerintah Berbasis Akrual pada Pemerinrah Daerah

Peraturan Pemerintah No. 24 tahun 2005 tentang Standar Akuntansi Pemerintah (SAP).

Peraturan Pemerintah No. 71 tahun 2010 tentang Standar Akuntansi Pemerintah Berbasis Akrual. 
Robbins. P.S.,2002, Prinsip-prinsip Perlaku Organisasi

Saleh and Pendlebury. (2006). Insentif biaya tahunan beasiswa bagi akuntan pemerintah untuk mengikuti kursus yang mengarah pada kualitas akuntansi Prefesional.

Satori, Djam'an dan Aan Komariah. 2014. Metodologi Penelitian Kualitatif. Alfabeta. Bandung.

Setiawan, Guntur. (2004). Implementasi Dalam Birokrasi Pembangunan. Bandung: Remaja Rosdakarya Offset

Soekanto, Soerjono. 2009. Peranan Sosiologi Suatu Pengantar, Edisi Baru, Rajawali Pers, Jakarta.

Sugiyono. 2008. Metode penelitian kualitatif. Bandung: alfabeta

Sugiyono. 2014. Metode penelitian pendidikan pendekatan kuantitatif, kualitatif dan R\&D. Bandung: Alfabeta

Supranto, J. 2009. Statistik: Teori dan Aplikasi. Edisi 7. Jakarta: Erlangga.

Supranto. 2007. Teknik Sampling Untuk Survey dan Eksperimen. Jakarta: Rineka Cipta.

Sutopo. 2006. Metodologi penelitian kualitatif. Surakarta: UAS

Suwardjono. 1986. Mengilustrasikan hubungan antara dasar akrual dengan penanding.

Undang Undang No. 17 tahun 2003 tentang perubahan sistem penganggaran dari tradisional budget menjadi penganggaran berbasis kinerja.

Widjajarso, Bambang. 2008. Penerapan Basis Akrual pada Akuntansi 